\title{
Quality of siltstones for concrete aggregate from Nallu Khola area, Kathmandu valley
}

\author{
*Dev Krishna Maharjan and Naresh Kazi Tamrakar \\ Central Department of Geology, Tribhuvan University, \\ Kirtipur, Kathmandu, Nepal \\ (*Email: dkmaharjn1@hotmail.com)
}

\begin{abstract}
The siltstones of the Tistung Formation are the major source of concrete aggregate in the Kathmandu valley. A number of quarries are operating in the valley, especially in the vicinity of the Nallu Khola, for more than three decades. Randomly collected siltstone samples from both banks of the Nallu Khola were studied to reveal their petrography and chemical composition. Crushed rock fragments were investigated to determine their overall aggregate properties. Tests were carried out to determine shape, flakiness index, elongation index, degree of induration, Schmidt hammer value, dry density, water absorption value, aggregate crushing value, and aggregate impact value. The test results indicate that the aggregates are physically, mechanically, and chemically sound.
\end{abstract}

\section{INTRODUCTION}

Several stone quarries are in operation in the Kathmandu valley for more than three decades. They are concentrated mainly in the Halchok, Sitapaila, and Nallu Khola (Tikabhairav) areas (Fig. 1). The Cambrian rocks of the Tistung Formation (Stöcklin 1980) are well distributed in the vicinity of the Nallu Khola, in the southern part of the Kathmandu valley (Fig. 1). Among siltstones, sandstones, and shales characterising the Tistung Formation, the siltstones predominate in the Nallu Khola area. The aggregates produced are supplied to the urban areas without any technical specifications. Hence, this study aims at evaluating the suitability of siltstones for concrete aggregates based on their rock mass characteristics, petrographic study, physical and chemical durability, and mechanical properties.

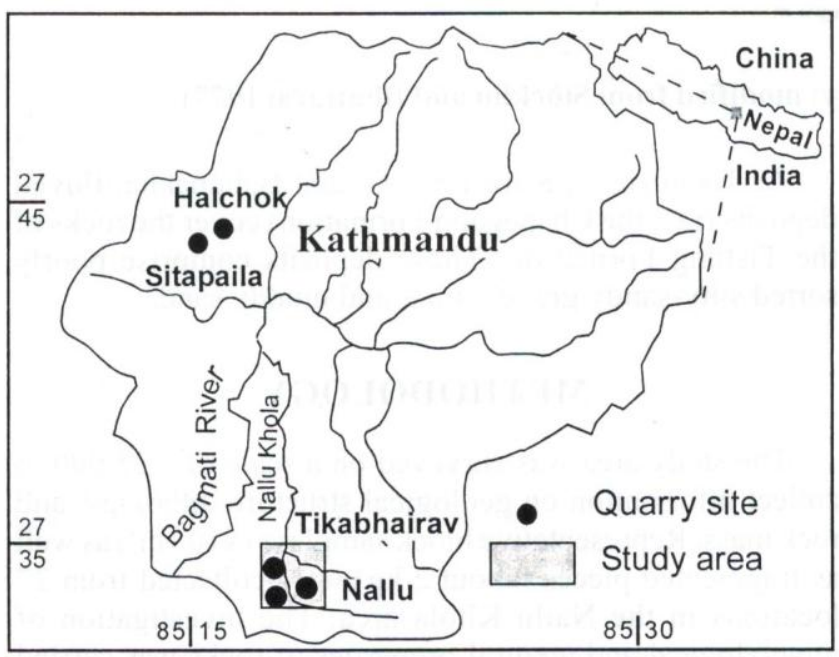

Fig. 1: Maps showing Location of study area

\section{GEOLOGICAL SETTING}

The Nallu Khola flows northwards and confluences with the Lele Khola giving rise to the Nakhu Khola (Fig. 2). A thick sequence of the Tistung Formation crops out on both banks of the Nallu Khola and on the uphill side of the road between Tikabhairav and Nayagaun (SE of the study area). Generally, beds strike NW-SE and dip $40^{\circ} \mathrm{NE}$. In the middle part of the Nallu Khola area, beds are folded and plunge due northwest. Vertical faults trending NW-SE and a few lineaments are also reported from the Nallu Khola area (Stöcklin and Bhattarai 1977).

The Tistung Formation consists of medium- to thickbedded, platy to blocky, and light bluish grey siltstone with thin intercalations of sandstone and shale. Rhythmic clastic sequences are observed in the lower, middle, and upper parts of the formation. In the southern region of the study area (locations 1, 2, 3, 4; Fig. 2), the siltstones are medium- to thick-bedded, laminated, and light grey. At location 6, strata show fining-upward sequences, and dip north-westward with an amount less than $45^{\circ}$. They are moderately to slightly weathered, medium- to thick-bedded, and light grey (Fig. 3a). They often contain joints with plumose structures. At locations 9, 10,11, and 12, strata extend to NE-SW and $\operatorname{dip} 30^{\circ}$ due NW. The exposure comprises thin- to mediumbedded, light grey siltstone (Fig. 3b).

In the middle part of the study area, at locations 13, 14, 15 , and 16 (Fig. 2), the siltstones are slabby to massive, medium- to thick-bedded, laminated, and light grey. At present, the left bank of the Nallu Khola is being mined (Fig. 3c, 3d). At Sikharwa (locations 17, 18, and 19; Fig. 2), the strata strike NE-SW and dip $30-60^{\circ}$ due NW. They are thin- to medium-bedded, moderately weathered, laminated, and light grey. 


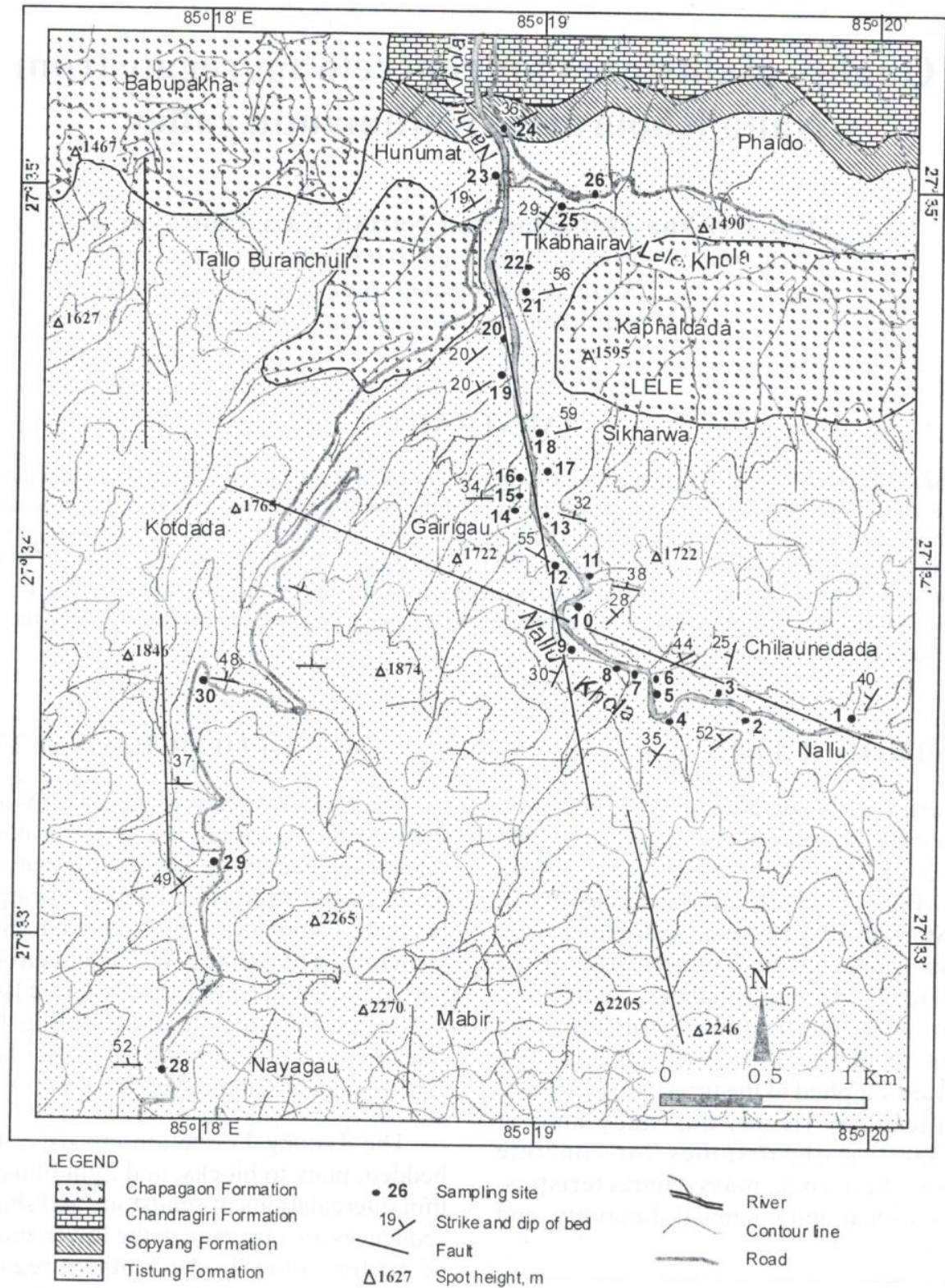

Fig. 2: Geological map with sampling sites (Geology: modified from Stöcklin and Bhattarai 1977)

In the northern part, at Tikabhairav (localities 20,21 and 22), strata are well exposed on both banks of the Nallu Khola. The siltstones exposed there are medium- to thick-bedded, slabby to blocky, and light grey (Fig. 3c). They contain oscillation ripple marks and exhibit fining-upward gradation. At locations 23, 24, 25 and 26, strata dip northwards at $30-40^{\circ}$. Siltstones therein are slightly weathered, medium bedded, and light grey.

On the right bank of the Nakhu Khola, about $150 \mathrm{~m}$ downstream from the bridge, a transitional contact between the Tistung and overlying Sopyang Formations is observed. The Sopyang Formation contains thinly bedded and laminated dark grey calcareous slates.
At Tikabhairav, Kaphaldanda, and Babupakha, fluvial deposits (i.e., the Chapagaon Formation) cover the rocks of the Tistung Formation. These deposits comprise poorly sorted silty-sandy gravel, mud, and muddy sand.

\section{METHODOLOGY}

The study area was surveyed on a scale of 1:25,000 to collect information on geological structure, lithology, and rock mass. Representative block samples $\left(1 \times 10^{-3} \mathrm{~m}^{3}\right)$ as well as fragmented pieces (about $2 \mathrm{~kg}$ ) were collected from 27 locations in the Nallu Khola area. The investigation of mineralogical and textural properties of rocks was carried 

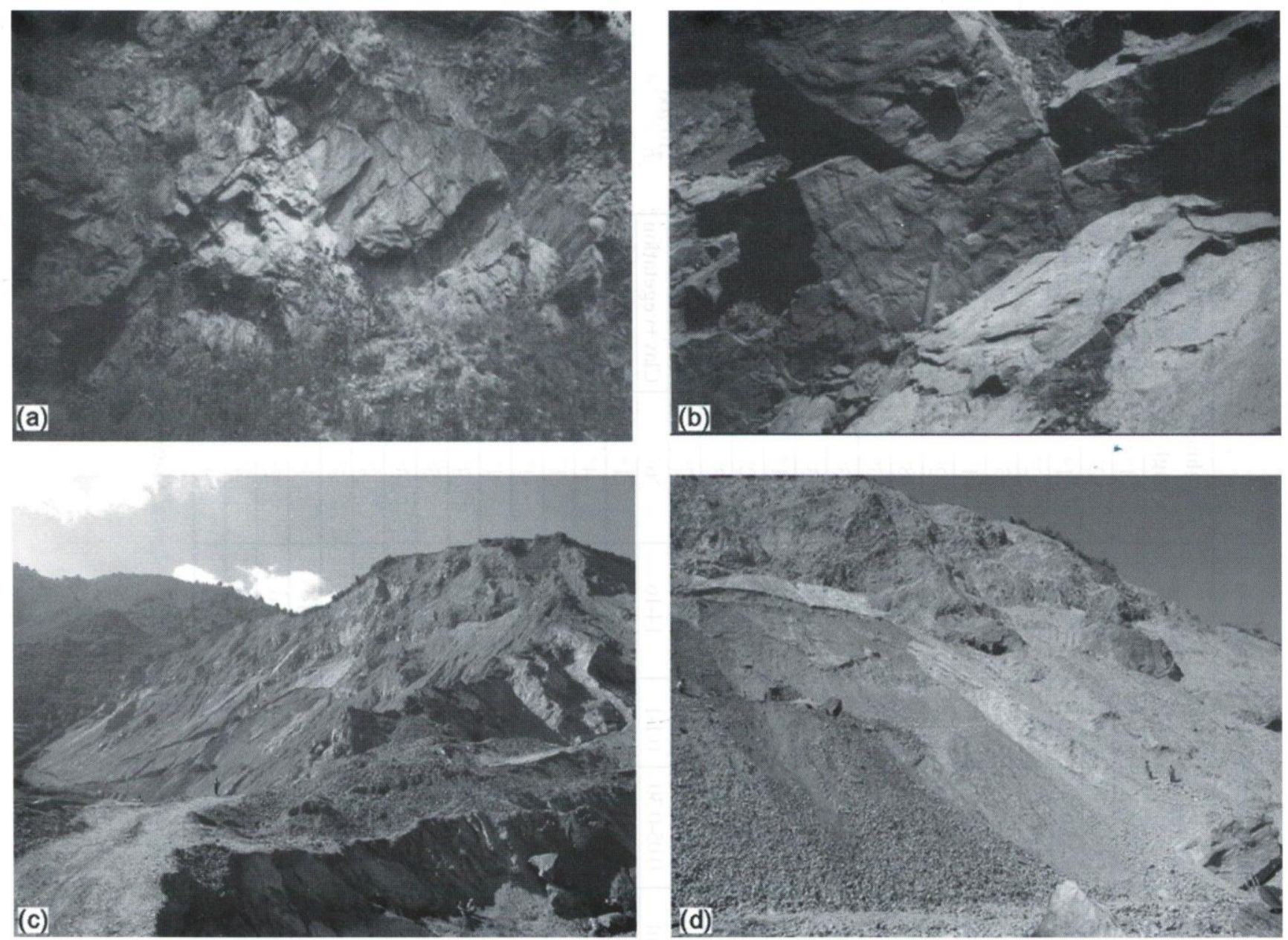

Fig. 3: Outcrops of rocks exposed in the banks and hill slopes of the Nallu Khola

out by studying the thin sections under the polarising microscope. From the block samples, separate cores were obtained for determining their physical properties and durability measures. The fragmented samples were utilised in determining durability measures, shape parameters using axial ratios as well as petrographic image analysis, aggregate crushing value, and aggregate impact value. The data obtained from the petrographic study, physical and stiffness tests, and durability tests were used to evaluate the siltstones.

\section{ROCK MASS CHARACTERISTICS}

The rocks of the Tistung Formation contain two to four sets of joints (Table 1). In the southern part of the study area, three sets are found. The southeast-dipping joints predominate in these outcrops. In the middle region, the siltstones contain four sets of joints and most of them dip towards SW. The siltstones located in the northern part contain only two sets of diagonal joints. Joint spacing varies from 5 to $30 \mathrm{~cm}$ (moderate spacing) or 0.3 to $1 \mathrm{~m}$ (wide spacing).
Joints have a wide spacing in the siltstones at locations 3,4 , 24 and 25 , but have a moderate spacing in other areas.

Most of the discontinuities are persistent. Their roughness values lie within the range of 6 and 12 on the roughness scale of Barton and Choubey (1977). Their roughness angle frequently ranges from $2^{\circ}$ to $4^{\circ}$. The apertures of discontinuities range from 0.1 to $1 \mathrm{~mm}$ and they are often filled up with clay. The rock outcrops are faintly to slightly weathered according to the weathering classification of the Geological Society of London (1970). Persistent and closely-spaced joints with wide openings give rise to the fragile rock mass, but highly-spaced joints result in massive rocks.

\section{THIN SECTION STUDY}

Twenty-seven rock specimens were classified using the Munsell colour chart (Anon 1991). Their colour was defined in terms of hue, value, and chroma. Thin sections were prepared from 27 rock specimens and were stained for Kfeldspar applying Chayes method (Chayes 1952), and for 


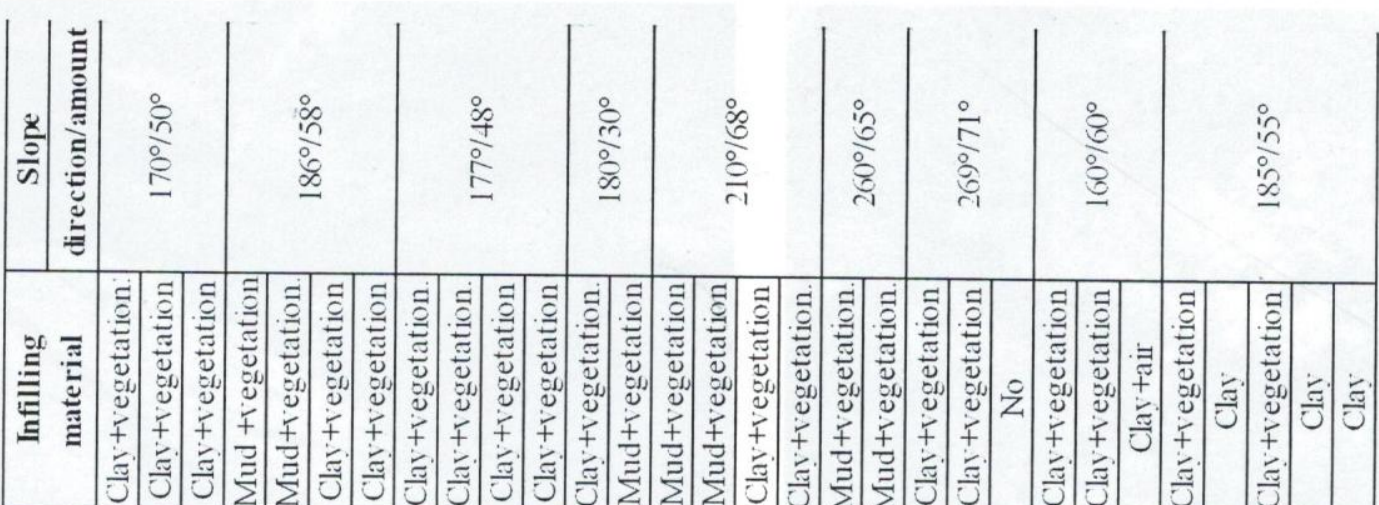
:

\begin{tabular}{|c|c|c|c|c|c|c|c|c|c|}
\hline 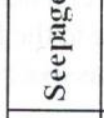 & $\cong$ & 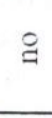 & $\cong$ & $\cong$ & g & g & g & $\cong$ & $\cong$ \\
\hline 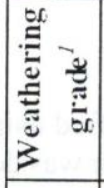 & 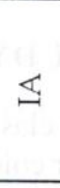 & 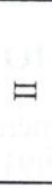 & ต & 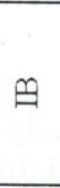 & 曰 & 曰 & 田 & 田 & 田 \\
\hline 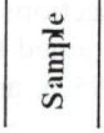 & - & -1 & $\mathrm{cr}$ & + & $a$ & $\varrho$ & $=$ & $\cong$ & $\stackrel{\infty}{\simeq}$ \\
\hline
\end{tabular}


Table 2: Results of analysis of thin sections of siltstone

\begin{tabular}{|c|c|c|c|c|c|c|c|c|c|c|c|}
\hline \multirow{2}{*}{$\begin{array}{l}\text { Sample } \\
\text { number }\end{array}$} & \multirow{2}{*}{\multicolumn{2}{|c|}{ Colour (hue/ value/ chroma) }} & \multirow{2}{*}{$\begin{array}{c}\text { Micro- } \\
\text { structure }\end{array}$} & \multirow{2}{*}{ Texture } & \multicolumn{7}{|c|}{ Composition, $\%$} \\
\hline & & & & & Quartz & Felds par & Mica & Heavies & Unidentified & Cement & Void \\
\hline 1 & $5 B 6 / 1$ & Light bluish grey & Massive & Medium silt & 73 & 1 & 7 & - & 3 & 16 & - \\
\hline 2 & $5 \mathrm{~B} 6 / 1$ & Light bluish grey & Massive & Coarse silt & 78 & - & 7 & - & 4 & 11 & - \\
\hline 3 & $5 B 6 / 1$ & Light bluish grey & Massive & Medium silt & 70 & 3 & 18 & - & - & 9 & - \\
\hline 4 & $5 B 7 / 1$ & Light bluish grey & Less foliated & Medium silt & 79 & 2 & 6 & 3 & - & 10 & - \\
\hline 5 & $5 \mathrm{~B} 6 / 1$ & Light bluish grey & Less foliated & Fine Silt & 78 & 1 & 6 & 2 & - & 13 & - \\
\hline 6 & $5 \mathrm{~B} 6 / 1$ & Light bluish grey & Less foliated & Medium silt & 65 & 1 & 22 & 3 & 3 & 6 & - \\
\hline 7 & $5 \mathrm{~B} 6 / 1$ & Light bluish grey & Massive & Coarse silt & 68 & 1 & 18 & 2 & - & 9 & 2 \\
\hline 8 & $5 \mathrm{~B} 6 / 1$ & Light bluish grey & Well foliated & Coarse silt & 85 & 2 & 4 & 2 & 2 & 5 & - \\
\hline 9 & $5 \mathrm{~B} 6 / 1$ & Light bluish grey & Well foliated & Fine silt & 81 & 1 & 10 & 3 & - & 3 & 2 \\
\hline 10 & $5 \mathrm{~B} 6 / 1$ & Light bluish grey & Massive & Coarse silt & 73 & 1 & 20 & 2 & 1 & 3 & - \\
\hline 11 & $5 \mathrm{~B} 6 / 1$ & Light bluish grey & Massive & Coarse silt & 76 & 1 & 5 & 2 & 5 & 11 & - \\
\hline 12 & $5 \mathrm{~B} 6 / 1$ & Light bluish grey & Massive & Coarse silt & 56 & - & 22 & 1 & 4 & 17 & - \\
\hline 15 & $5 \mathrm{~B} 6 / 1$ & Light bluish grey & Massive & Coarse silt & 59 & 2 & 23 & 1 & - & 15 & - \\
\hline 17 & $5 Y R 6 / 2$ & Pale brown & Less foliated & Fine silt & 82 & 1 & 3 & 2 & 5 & 2 & 5 \\
\hline 18 & $5 \mathrm{~B} 6 / 1$ & Light bluish grey & Well foliated & Coarse silt & 83 & 1 & 7 & 4 & 2 & 1 & 2 \\
\hline 19 & $5 Y 7 / 2$ & Yellowish grey & Massive & Coarse silt & 65 & - & 15 & 2 & 1 & 2 & 15 \\
\hline 20 & $5 B 7 / 1$ & Light bluish grey & Massive & Coarse silt & 80 & 1 & 8 & 2 & 2 & 5 & 2 \\
\hline 21 & $5 \mathrm{Y} 8 / 1$ & Yellowish grey & Foliated & Coarse silt & 78 & 1 & 12 & 1 & 2 & 5 & 1 \\
\hline 22 & $10 \mathrm{YR} 7 / 2$ & Pale yellowish brown & Massive & Coarse silt & 55 & - & 25 & 5 & 5 & 10 & - \\
\hline 23 & $10 Y R$ 8/4 & Grey ish orange & Massive & Fine silt & 65 & 2 & 8 & 17 & - & 8 & - \\
\hline 24 & $5 B 7 / 1$ & Light bluish grey & Massive & Medium silt & 50 & - & 21 & 12 & - & 17 & - \\
\hline 25 & $5 B 7 / 1$ & Light bluish grey & Less foliated & Coarse silt & 82 & - & 8 & 2 & - & 7 & 1 \\
\hline 26 & $10 Y R 7 / 2$ & Pale yellowish brown & Less foliated & Coarse silt & 81 & - & 6 & 2 & 4 & 5 & 2 \\
\hline 27 & 5YR 7/1 & Light brown ish grey & Less foliated & Coarse silt & 65 & 4 & 10 & 11 & - & 10 & - \\
\hline 28 & $10 Y R 7 / 2$ & Pale yellowish brown & Less foliated & Fine silt & 72 & 1 & 7 & 11 & 2 & 7 & - \\
\hline 29 & 5YR 7/1 & Light brown ish grey & Less foliated & Fine silt & 65 & 3 & 6 & 12 & - & 14 & - \\
\hline 30 & $10 Y R 7 / 2$ & Pale yellowish brown & Less foliated & Coarse silt & 80 & 1 & 5 & 8 & - & 6 & - \\
\hline
\end{tabular}
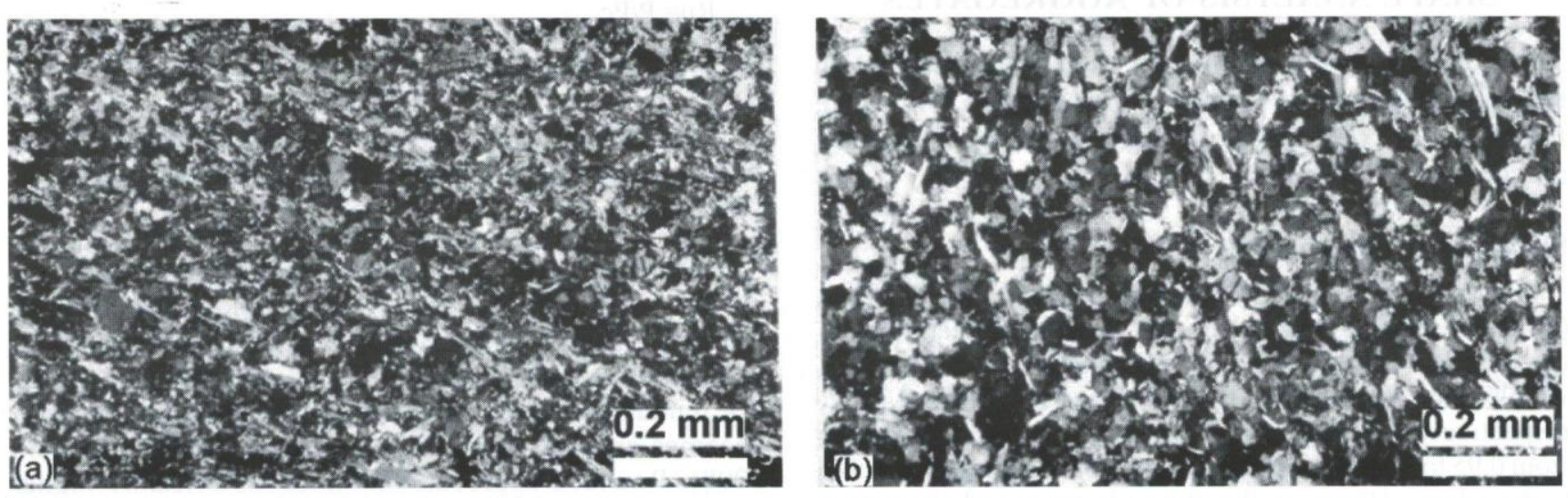

Fig. 4: Photomicrographs of siltstone; (a) Interlocked and elongate quartz grains and micas (location 9) and (b) interlocked quartz grains (Location 15)

swelling clay mineral (smectite) using methylene blue. Composition of rocks was determined following the pointcounting method of Blackburn and Dennen (1988). Their colour, microstructure, texture, and composition are listed in Table 2 .

Most of the light bluish grey specimens are fresh. Some samples show pale yellowish brown and light brownish grey colours resulted due to ferruginous cements and a few altered grains. Siltstones are frequently massive to wellfoliated (Fig. 4a) and sporadically less foliated (Fig 4b). Their grain size varies from fine to coarse silt.

Quartz is the dominant mineral in all the samples, whereas feldspar, mica, and heavy minerals constitute a minor proportion. In some samples, micas (mainly muscovite) represent around $20 \%$, where fresh authigenic muscovite displays sharp boundaries. The rock is normally free of voids and cemented mostly by authigenic silica with sporadic argillaceous and ferruginous material. Generally, subrounded quartz grains are interlocked. In some sections, elongated quartz grains are aligned parallel to the foliation.

Most of the rocks are slightly foliated. Samples 8, 9, and 18 are well foliated, in which quartz- and mica-rich bands can be distinguished. A high proportion of quartz with strong siliceous cement and interlocked grains make the siltstones indurated. 


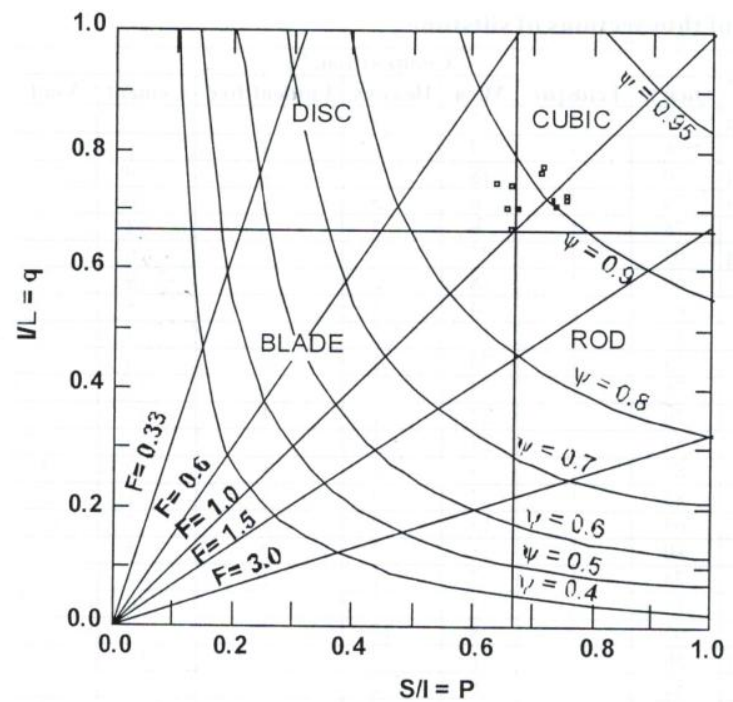

Fig. 5: Shape diagram indicating mean forms of aggregate samples

\section{SHAPE ANALYSIS OF AGGREGATES}

The aggregates were studied for their shape factor (F), sphericity $(\Psi)$, roughness index $(R u)$, roundness index $(R n)$, flakiness index (FI), and elongation index (EI). The results are summarised in Table 3.

\section{Shape factor and sphericity}

Based on the longest (L), intermediate (I), and shortest (S) dimensions of each grain, the shape was quantified in terms of flatness ratio $(p=S / I)$ and elongation ratio $(q=I / L)$, which range from 0.6307 to 0.7491 and 0.6597 to 0.7722 , respectively. Shape factor $(\mathrm{F})$ is the ratio $\mathrm{q} / \mathrm{p}$, and ranges from 0.95 to 1.18 in most of the samples indicating their cubic to disc shape. However, the plot of flatness and elongation ratios indicates that the aggregate grains are mostly of cubic shape (Fig. 5).

Sphericity was calculated using the flatness and elongation ratios (Janoo 1998) as given below.

$$
\psi=\frac{12.8\left(\sqrt[3]{p^{2} q}\right)}{1+p(1+q)+6 \sqrt{1+p^{2}\left(1+q^{2}\right)}}
$$

It ranges from 0.863 to 0.926 (Table 3 ) and shows that the grains possess high sphericity.

\section{Roughness and roundness}

Roughness and roundness indices of Janoo (1998) were measured using the computer software NIH Scion Image Analyser and were calculated from the following relations.

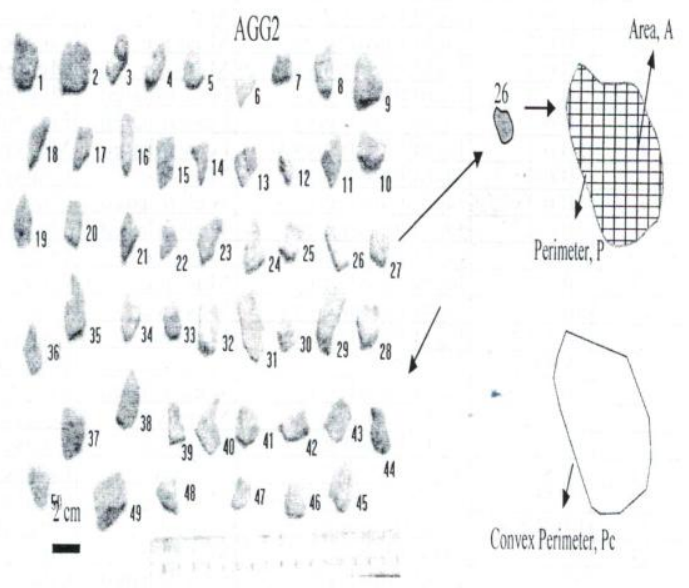

Fig. 6: Determination of perimeter and area of a grain. Sample 26 shown as an example.

$\mathrm{Ru}=\mathrm{P} / \mathrm{Pc}$

$\mathrm{Rn}=4 . \pi \cdot \mathrm{A} / \mathrm{P}^{2} \cdot 100$

where $\mathrm{Ru}$ is roughness index, $\mathrm{Rn}$ is roundness index, $\mathrm{A}$ is area of particle, $\mathrm{P}$ is perimeter, and $\mathrm{Pc}$ is convex perimeter (Fig. 6).

For a smooth material, the roughness index equals unity. As the roughness increases, the roughness index also increases. Rough aggregates are desirable because their workability with cement is good (Kaplan 1961; Neville 1996). The roundness index of a perfect circle is 100 . As the material becomes angular, the roundness index decreases (Janoo 1998). Rounded aggregates produce significantly higher permanent deformation than angular ones. Rounded particles easily slip whereas angular ones have to overcome higher frictional forces at contact interfaces during compression (Holtz and Kovacs 1981). Internal friction angle increases with increasing angularity and surface roughness (Holtz and Kovacs 1981).

The roughness index of siltstone grains ranges from 1.19 to 1.30 , whereas their roundness index varies from 49.77 to 58.62 (Table 3 ). Most of the aggregate grains show relatively high roughness and moderate roundness.

\section{Flakiness and elongation indices}

Flakiness and elongation indices were determined using the methods of determining particle shape by British Standard Institution $(1975 ; 1989)$. For determining flakiness index (FI) and elongation index (EI), eleven aggregate samples, each with 50 grains were used. For EI, the aggregate 
Table 3: Results of shape analyses of aggregates

\begin{tabular}{|c|c|c|c|c|c|c|c|c|c|c|c|c|}
\hline \multirow[b]{2}{*}{ Sample } & \multicolumn{5}{|c|}{ Parameters from axial ratio meas urement } & \multicolumn{5}{|c|}{ Parameters from image analys is } & \multicolumn{2}{|c|}{ BS812 } \\
\hline & $\mathbf{p}$ & q & $\mathbf{F}$ & Form & $\mathbf{Y}$ & \begin{tabular}{|c|}
$\mathrm{P}$ \\
pixel
\end{tabular} & $\begin{array}{c}\mathrm{Pc} \\
\text { pixel }\end{array}$ & A (sq pixel) & $\mathrm{Ru}$ & Rn & FI $(\%)$ & EI $(\%)$ \\
\hline 1 & 0.67 & 0.70 & 1.05 & cubic & 0.879 & 70.32 & 57.26 & 207067.81 & 1.23 & 53.31 & 16.7 & 59.6 \\
\hline 2 & 0.66 & 0.74 & 1.13 & disc & 0.891 & 67.06 & 52.73 & 183368.32 & 1.27 & 51.91 & 22.1 & 83.2 \\
\hline 5 & 0.73 & 0.72 & 0.99 & cubic & 0.911 & 74.42 & 62.81 & 255018.29 & 1.19 & 58.62 & 22.9 & 68.3 \\
\hline 6 & 0.66 & 0.66 & 1.00 & disc & 0.863 & \begin{tabular}{|l|}
81.02 \\
\end{tabular} & 65.07 & 266679.22 & 1.24 & 51.72 & 18.9 & 57.9 \\
\hline 9 & 0.75 & 0.72 & 0.95 & cubic & 0.909 & \begin{tabular}{|l|}
65.91 \\
\end{tabular} & 53.56 & 181637.40 & 1.23 & 53.23 & 18.8 & 82.7 \\
\hline 10 & 0.73 & 0.70 & 0.96 & cubic & 0.898 & \begin{tabular}{|l|}
75.90 \\
\end{tabular} & 61.57 & 225215.04 & 1.23 & 49.77 & 19.5 & 54.4 \\
\hline 11 & 0.75 & 0.72 & 0.97 & cubic & 0.905 & \begin{tabular}{|l|}
71.53 \\
\end{tabular} & 58.03 & 202157.86 & 1.23 & 50.3 & 14.5 & 59.6 \\
\hline 17 & 0.63 & 0.75 & 1.18 & disc & 0.878 & \begin{tabular}{|l|}
75.50 \\
\end{tabular} & 61.21 & 239727.83 & 1.23 & 53.54 & 17.2 & 48.8 \\
\hline 20 & 0.71 & 0.77 & 1.08 & cubic & 0.905 & \begin{tabular}{|l|}
75.39 \\
\end{tabular} & 60.88 & 238449.41 & 1.24 & 53.41 & $15.9=$ & 64.0 \\
\hline 21 & 0.71 & 0.77 & 1.09 & cubic & 0.918 & \begin{tabular}{|l|}
70.41 \\
\end{tabular} & 55.14 & 195682.03 & 1.30 & 50.25 & 11.3 & 66.9 \\
\hline 23 & 0.65 & 0.70 & 1.08 & disc & 0.926 & 73.60 & 60.26 & 225133.22 & 1.22 & 52.91 & 18.0 & 40.9 \\
\hline
\end{tabular}

of size 10 to $14 \mathrm{~mm}$ was weighed. The aggregate was passed through the length gauge of width $21.6 \pm 0.2 \mathrm{~mm}$, such that the greatest grain dimension was aligned along the two pins of the gauge. The fraction, which did not pass through the gauge, was weighed. EI was calculated as

$$
E I=\frac{y}{w} \cdot 100 \%
$$

where $y$ is weight of the fraction not passing through the length gauge, and $w$ is the weight of the test sample.

FI was determined using the thickness gauge of length $26.4 \mathrm{~mm}$ and width $6.6 \mathrm{~mm}$. For this test, the aggregate sample of size 9.5 to $13.2 \mathrm{~mm}$ was weighed. Each aggregate grain was allowed to pass though the thickness gauge. The fraction, which passed through the slot, was weighed. FI was calculated as below:

$$
F I=\frac{x}{w} \cdot 100 \%
$$

where $x$ is weight of the fraction passing through the thickness gauge, and $w$ is the weight of the test sample.

A low percentage of FI shows that the aggregates contain only a few flat grains. The high percentage of EI indicates the presence of a small number of elongated grains. In the studied samples, FI ranges from 14 to $22 \%$ and EI varies from 40.87 to $83.17 \%$ (Table 3 ) indicating that there are not many flat or elongated grains.

\section{DRY DENSITY AND WATER ABSORPTION VALUE}

The physical properties of aggregate, such as dry density $\left(\rho_{\text {dry }}\right)$ and water absorption value (WAV), were measured. Dry density and WAV were determined for cylindrical samples according to calliper and saturation method (ISRM 1979).
The dry density of samples ranges from $2126 \mathrm{~kg} / \mathrm{m}^{3}$ to $2745 \mathrm{~kg} / \mathrm{m}^{3}$ with an average value of $2585 \mathrm{~kg} / \mathrm{m}^{3}$. Most samples bear less than $1 \%$ WAV (Table 4 ), thus showing very low effective porosity. Only few siltstones from the north of the study area contain WAV between 1.0 and $6.6 \%$. The dry density values indicate that the siltstones are much denser than lightweight aggregates. Low WAV indicates low accessibility for water to pass through the intact rock.

\section{Stiffness}

Stiffness of aggregate grains was evaluated based on Schmidt hammer test, induration, aggregate crushing value $(\mathrm{ACV})$, and aggregate impact value (AIV).

\section{Schmidt hammer test}

Schmidt rebound hammer test was carried out in in-situ siltstones using an L-type hammer. Out of 20 observations, the higher 10 values were averaged and taken as the Schmidt hammer value (SHV), which ranges from 32 to 56 (Table 4). The SHVs were used along with the density of samples to derive the unconfined compressive strength (UCS) according to Deere and Miller (1966). The UCS ranges from 45 to 180 $\mathrm{MPa}$, which indicates that the siltstones belong to mediumto high-strength rocks.

\section{Induration}

Induration indicates the degree of freshness or stiffness of rock or rock material. The induration of intact rock specimen was measured following Larsen et al. (1995). Most of the samples fall on $\mathrm{H} 4$ (i.e., strongly indurated) and H5 (i.e., very strongly indurated), and a few on $\mathrm{H} 3$ (i.e., indurated) categories. The strongly to very strongly indurated samples are compact and well interlocked.

\section{Crushing and impact values}

Aggregate crushing value (ACV) and aggregate impact value (AIV) were determined using a compression testing 
machine and a hammer, respectively following ASTM (1979). ACV provides a relative measure of resistance to crushing under a gradually applied compressive load. To achieve a good quality of aggregate, low ACV is preferred (ASTM 1979). ACV was obtained using the equation:

$$
A C V=\frac{W 2}{W 1} \times 100 \%
$$

where $\mathrm{W} 1$ = total weight of test sample $(\mathrm{g})$ and $\mathrm{W} 2=$ weight of aggregate passing $4.75 \mathrm{~mm}$ sieve after the test (g).

The ACV of siltstones ranges from 22.13 to $31.96 \%$ (Table 4). It is satisfactory for using as the concrete aggregate, but the desirable value is $<16 \%$ for road pavement design.

AIV was calculated using the following equation:

$$
A I V=\frac{W 3}{W 1} \times 100 \%
$$

where $\mathrm{W} 1$ = weight of original sample and W3 = weight of the fraction after the test, passing through 2.36 sieve.
Hobbs (1964) related AIV with compressive strength to classify rocks with respect to their toughness. The AIV of siltstones ranges from 13.75 to $19.5 \%$, which belongs to the desirable range (10-20\%) according to ASTM (1979). This range also indicates that all the aggregates tested are strong (Hobbs 1964) and are resistant to impact. Therefore, these are suitable for pavements.

\section{DURABILITY}

To evaluate chemical and mechanical durability of aggregates against weathering, ethylene glycol soak test, methylene blue absorption test, and magnesium sulphate soundness test were performed.

\section{Ethylene glycol soak test}

Ethylene glycol causes rapid expansion of swelling clays by penetrating into their lattice. The core samples were immersed in ethylene glycol for 30 days. Then, a degree of disintegration and time required to approach the worst

\begin{tabular}{|c|c|c|c|c|c|c|c|c|c|c|}
\hline \multirow[b]{2}{*}{ Sample } & \multicolumn{2}{|c|}{ Physical properties } & \multirow[b]{2}{*}{ SHV } & \multicolumn{3}{|c|}{ Stiffness measures } & \multirow[b]{2}{*}{$\begin{array}{c}\text { AIV } \\
\%\end{array}$} & \multicolumn{3}{|c|}{ Durability measures } \\
\hline & $\begin{array}{c}\text { WAV } \\
\% \\
\end{array}$ & $\begin{array}{c}\text { Dry density } \\
\mathrm{Kg} / \mathrm{m}^{3} \\
\end{array}$ & & $\begin{array}{l}\mathrm{UCS}^{\prime} \\
\text { Мpa }\end{array}$ & Induration $^{2}$ & $\begin{array}{c}\mathrm{ACV} \\
\% \\
\end{array}$ & & STI & $\begin{array}{c}\text { MBAV } \\
\% \\
\end{array}$ & $\begin{array}{c}\text { MSV } \\
\%\end{array}$ \\
\hline 1 & 0.71 & 2550 & 48 & 125 & $\mathrm{H} 4$ & 23.3 & 14.9 & 1 & $<1 \%$ & 0.25 \\
\hline 2 & 0.22 & 2683 & 47 & 113 & $\mathrm{H} 4$ & 23.4 & 13.8 & 1 & $<1 \%$ & 13.6 \\
\hline 3 & 0.40 & 2740 & 48 & 125 & $\mathrm{H} 3$ & 23.1 & 15.0 & 1 & $<1 \%$ & - \\
\hline 4 & 0.40 & 2607 & 47 & 113 & $\mathrm{H} 4$ & 23.8 & 15.4 & 1 & $<1 \%$ & - \\
\hline 5 & 0.19 & 2253 & 48 & 125 & $\mathrm{H} 3$ & 22.1 & 15.0 & 1 & $<1 \%$ & 13 \\
\hline 6 & 0.31 & 2679 & 50 & 140 & $\mathrm{H} 4$ & 22.7 & 14.3 & 1 & $<1 \%$ & 0.4 \\
\hline 7 & 0.17 & 2700 & 46 & 100 & $\mathrm{H} 4$ & 24.2 & 16.3 & 1 & $<1 \%$ & - \\
\hline 9 & 0.57 & 2664 & 46 & 100 & $\mathrm{H} 4$ & 22.5 & 13.8 & 1 & $<1 \%$ & 2.06 \\
\hline 10 & 0.52 & 2711 & 49 & 132 & $\mathrm{H} 3$ & 23.0 & 14.7 & 1 & $<1 \%$ & 0.47 \\
\hline 11 & 0.30 & 2657 & 51 & 147 & $\mathrm{H} 5$ & 22.7 & 14.7 & 1 & $<1 \%$ & 0.33 \\
\hline 12 & 0.20 & 2744 & 51 & 147 & $\mathrm{H} 4$ & 22.6 & 14.6 & 1 & $<1 \%$ & - \\
\hline 13 & 0.63 & 2745 & 56 & 180 & $\mathrm{H} 3$ & 21.2 & 14.7 & 1 & $<1 \%$ & - \\
\hline 14 & 0.20 & 2739 & 52 & 150 & $\mathrm{H} 3$ & 23.3 & 15.5 & 1 & $<1 \%$ & - \\
\hline 15 & 0.22 & 2749 & 40 & 75 & $\mathrm{H} 3$ & 25.2 & 17.0 & 1 & $<1 \%$ & - \\
\hline 17 & 0.18 & 2493 & 38 & 70 & $\mathrm{H} 5$ & 25.4 & 17.2 & 1 & $<1 \%$ & 0.62 \\
\hline 18 & 0.26 & 2650 & 39 & 73 & $\mathrm{H} 4$ & 25.3 & 17.1 & 1 & $<1 \%$ & - \\
\hline 19 & 2.70 & 2570 & 34 & 56 & $\mathrm{H} 3$ & 28.3 & 19.5 & 1 & $<1 \%$ & - \\
\hline 20 & 1.87 & 2476 & 32 & 50 & $\mathrm{H} 4$ & 26.1 & 18.1 & 1 & $<1 \%$ & 0.59 \\
\hline 21 & 1.86 & 2538 & 29 & 45 & $\mathrm{H} 3$ & 24.7 & 19.5 & 1 & $<1 \%$ & 0.48 \\
\hline 22 & 3.37 & 2451 & 43 & 90 & $\mathrm{H} 3$ & 25.3 & 15.0 & 1 & $<1 \%$ & - \\
\hline 23 & 6.60 & 2126 & 47 & 113 & $\mathrm{H} 3$ & 23.8 & 15.4 & 1 & $<1 \%$ & 0.53 \\
\hline 24 & 1.30 & 2596 & 43 & 90 & $\mathrm{H} 3$ & 25.4 & 15.5 & 1 & $<1 \%$ & - \\
\hline 25 & 0.60 & 2711 & 42 & 85 & $\mathrm{H} 4$ & 24.8 & 16.6 & 1 & $<1 \%$ & - \\
\hline 26 & 1.36 & 2647 & 32 & 50 & $\mathrm{H} 4$ & 26.1 & 18.1 & 1 & $<1 \%$ & - \\
\hline 27 & 1.23 & 2548 & 38 & 70 & $\mathrm{H} 5$ & 25.4 & 17.2 & 1 & $<1 \%$ & - \\
\hline 28 & 2.78 & 2347 & 35 & 58 & $\mathrm{H} 4$ & 25.8 & 17.7 & 1 & $<1 \%$ & - \\
\hline 29 & 0.77 & 2638 & 40 & 75 & H5 & 25.2 & 17.0 & 1 & $<1 \%$ & - \\
\hline 30 & 2.96 & 2433 & 38 & 70 & $\mathrm{H} 4$ & 25.4 & 17.2 & 1 & $<1 \%$ & - \\
\hline
\end{tabular}

Table 4: Physical properties, stiffness measures and durability of siltstone

'Estimated using chart of Deere and miller (1966); ${ }^{2}$ Larsen et al. (1995), H1-Indurated, H4-Strongly indurated, H5-Very strongly indurated 
condition were recorded (Haskins and Bell 1995) to obtain the soak test index (STI). The index was equal to 1 for all the samples. It showed that the samples are unaffected by ethylene glycol, which is explained either by a low proportion of swelling clays or their low effective porosity. Therefore, the samples are quite resistant to chemical weathering.

\section{Methylene blue adsorption value (MBAV)}

In this test, thin sections of siltstones were treated with methylene blue solution $(0.5 \mathrm{~g}$ methylene blue $+125 \mathrm{ml}$ distilled water $+125 \mathrm{ml}$ ethanol). The assumption made was that swelling clays are affected by the methylene blue because of cation exchange capacity (Hang and Brindley 1970). A per cent count of area occupied by blue dye in the thin sections (i.e., MBAV) was determined under a polarising microscope. As the value was less than $1 \%$, the samples contain a negligible amount of swelling clays.

\section{Magnesium sulphate value}

Magnesium sulphate value (MSV) is the measure of soundness of aggregate. The aggregates of size 10-14 mm and of weight $425 \pm 5 \mathrm{~g}$ were immersed in the magnesium sulphate solution of density $1.292 \pm 0.008 \mathrm{~g} / \mathrm{ml}$ for 48 hours and were subsequently dried out. The process was repeated for five times. MSV was calculated as below.
$M S V=\frac{(M 1-M 2)}{M 1} \times 100 \%$

where $\mathrm{M} 1=$ initial mass of the test specimen and $\mathrm{M} 2=$ the mass of the specimen retained on $10 \mathrm{~mm}$ sieve after the fifth cycle.

An MSV greater than 15\% implies frost susceptibility. Since MSV varies from 0.21 to $13.64 \%$ in the tested samples, they are frost resistant.

\section{SUITABILITY OF SILTSTONES}

Table 5 presents a comparison of the obtained test results with the desired indices. The siltstones from-locations 15 to 22 and 24 to 30 possess slightly higher ACV and AIV, lower SHV and UCS, and higher WAV than the rest (i.e., locations 1 to 14 , and 23).

The texture of aggregate grains is angular and rough. Their EI is high and FI is low, indicating that the siltstones give rise to a low amount of flat and elongate grains when crushed. The siltstones therefore have good workability with cement.

The siltstones bear less than 4\% WAV, indicating very low effective porosity that prevents the solvents from penetrating into them. Dry density of siltstones lies in the intermediate-weight range (between 2000 and $3000 \mathrm{~kg} / \mathrm{m}^{3}$ ).

Table 5: Evalutation of siltstone the Nallu Khola area

\begin{tabular}{|c|c|c|c|}
\hline Aggregate property & Desirable value & Obtained value & Remarks \\
\hline Roundness/roughness & Angular/rough & Angular/rough & Angular with rough surface text ure \\
\hline Form/sphericity & cubic to bladed and high sphericity & & \\
\hline Flakiness index $(\mathrm{FI})$ & Low & $14-22 \%$ & Low amount of flate particles. \\
\hline Elongation index $(\mathrm{EI})$ & High & $40.87-83.17$ & Low amount of elongate particles \\
\hline Weathering grade & I to $\mathrm{Ib}$ & Ib-II & Rocks are nearly fresh \\
\hline Induration & $\begin{array}{l}\mathrm{H} 3 \text { to } \mathrm{H} 5 \text { indurated to } \\
\text { very strongly indurated }\end{array}$ & $\mathrm{H} 3-\mathrm{H} 4$ & Indurated to strongly indurated rocks \\
\hline WAV & $<1 \%$ to $5 \%$ (<3\% reasonable $)$ & $0.20-3.37 \%$ & Low effective porosity \\
\hline Dry density & $2000-3000 \mathrm{Kg} / \mathrm{m}^{3}$ & $2126-2745 \mathrm{~kg} / \mathrm{m}^{3}$ & Medium weight aggregate \\
\hline \multirow{2}{*}{ UCS } & $110-221 \mathrm{Mpa}$ (high strength) & $45-180 \mathrm{Mpa}$ & \multirow[t]{2}{*}{ Medium to high strength rock } \\
\hline & 55-1 $10 \mathrm{Mpa}$ (medium strength) & & \\
\hline $\mathrm{ACV}$ & $<16 \%$ to $25 \%$ & $22.027-28.3 \%$ & Strong rock \\
\hline AIV & $10-20$ (strong rock) & $13.75-19.5 \%$ & Strong rock \\
\hline \multirow[b]{2}{*}{ STI } & $1=$ no obvious effects within 30 days & 1 & \multirow[t]{2}{*}{ Highly resistant to chemical weathering } \\
\hline & $\begin{array}{l}2=\text { minor spalling of particles } \\
\text { between } 21 \text { and } 30 \text { days }\end{array}$ & & \\
\hline MBAV & $<1 \%$ & $<1 \%$ & Sound and low amount of swelling clay \\
\hline MSV & $<15 \%$ & $0.21-13.64 \%$ & Resistant to freeze and thaw \\
\hline
\end{tabular}




\section{K. Maharjan and N. K. Tamrakar}

The siltstones are nearly fresh to faintly weathered, as indicated by classes Ib and II in Table 1. They fall between $\mathrm{H} 3$ to $\mathrm{H} 5$ categories of induration (Table 4). UCS values show that the siltstones are of medium to high strength. ACV and AIV of siltstones also indicate that they are strong rocks.

STI and MSV of the siltstones are 1 and less than $15 \%$, respectively. These parameters indicate that the siltstones are resistant to chemical and mechanical weathering. Similarly, MBAV shows that the swelling clay is present in an insignificant amount, and therefore the rock is also resistant to swelling.

\section{CONCLUSIONS}

The siltstones from the Nallu Khola area are faintly to slightly weathered and possess 2 to 4 sets of joints. The siltstones are medium- to coarse-grained, quartz-rich, and their grains are interlocked by siliceous cement. They contain some authigenic micas also. The aggregate grains derived from crushing are almost cubic in shape. They are rough and angular with good workability potential.

The degree of induration, UCS, ACV, and AIV of the grains show that the siltstones are mechanically sound. They belong to medium-weight aggregates. Low WAV, STI, MBAV and MSV of the siltstones indicate that the rock is resistant to frost and chemical weathering. As most of the obtained values from different tests are within the desirable limits, the siltstones are appropriate for concrete aggregates.

\section{ACKNOWLEDGEMENT}

We thank Dr P. C. Adhikary, Head, Central Department of Geology, Tribhuvan University, Kirtipur, Kathmandu, Nepal, for providing the laboratory facilities.

\section{REFERENCES}

Anon, 1991, Rock color chart, Geological Society of America (Munsell color).

ASTM, 1979, Standard method of test for triaxial compressive strength of undrained rock core specimens without pore pressure measurements. American Soc. Test. Material, Annual Book of ASTM Standards, 632 p.

Barton, N. and Choubey, V., 1977, The shear of Rock Joints in Theory and Practice, v. 10, pp. 1-54.
Blackburn W. H. and Dennen W. H., 1988, Principles of mineralogy, second edition, Wm. C. Brawn Publisher, 443 p.

British Standard Institution, 1975, Methods of determination of particle shape. BS 812, part 1, BSI, London.

British Standard Institution, 1989, Methods of determination of particle shape. BS 812, part 105, BSI, London.

Chayes, F., 1952, Staining of potash feldspars with sodium cobaltinitrite in thin sections, American Minerals, v. 37 , pp. 337-390.

Deere, D. U. and Miller, R. P., 1966, Engineering classification and index properties for intact rocks. Tech Rep AFWL-TR Airforce Weapons Laboratory, New Mexico, pp. 65-116.

Geological Society of London, 1970, The logging of rock cores for engineering purposes; Geol. Soc. (London) Eng. Group Working Party, Q. Jour. Engg. Geol., v. 3, pp. 1-24.

Hang, P. T., Brindley, G. W., 1970, Methylene blue adsorption by clay minerals, determination of surface area and cation exchange capacities. Clay Organic Studies XVIII, Clays and Clay Minerals, v. 18, pp. 203-221.

Haskins D. R. and Bell F. G., 1995, Darkensbery basalts; their alteration, breakdown and durability, Quarterly Jour. of Engg. Geol., v. 28 , pp. 287-302.

Hobbs D. W., 1964, Rock compressive strength, Coll. Engg., v. 14, pp. 287-292.

Holtz, R. D. and Kovacs, W. D., 1981, An introduction to Geotechnical engineering. Eaglewood Cliffs, New Jersey, Prentice-Hall, Inc.

ISRM, 1979, Suggested methods for determining water content, porosity, density, absorption and related properties and swelling and slake-durability index properties: Intl. Soc. Rock mech. Comm. on Standardization of Laboratory and Field Tests, Intl. Jour. Rock Mech. Min. Sci. and Geomech. Abstr., v. 16, pp. 141-156.

Janoo, V. C., 1998, Quantification of Shape, Angularity, and Surface Texture of Base Course Materials, US Army Corps of Engineers, Special Report 98-1, pp. 1-22.

Kaplan, M. F., 1961, Crack propagation and fracture of concrete, Jour. American concrete Institute, v. 58, pp. 591-610.

Larsen, F. J., Villumsen, A., Fredericia, J., Gravesen, P., Fojed, N., Knudsen, B., and Baumann, J., 1995, A Guide to Engineering Geological soil Description, Danish Geotechnical Society, Bulletins.

Neville, A. M., 1996, Properties of concrete. Fourth edition, Addison Wesley Longman, Essex, England.

Stöcklin, J., 1980, Geology of Nepal and its regional frame, Jour Geol. Soc. London, v. 137, pp. 1-34.

Stöcklin, J. and Bhattarai, K. D., 1977, Geology of Kathmandu Area and central Mahabharat Range, Nepal Himalaya. Kathmandu: HMG/UNDP Mineral Exploration Project, Technical Report, New York, 64 p. (Unpublished). 